Journal of Teacher Education for Sustainability, vol. 16, no. 1, pp. 89-101, 2014

\title{
Teaching Methods Influencing the Sustainability of the Teaching Process in Technology Education in General Education Schools
}

\author{
Mart Soobik \\ University of Tallinn, Estonia
}

\begin{abstract}
The sustainability of technology education is related to a traditional understanding of craft and the methods used to teach it; however, the methods used in the teaching process have been influenced by the innovative changes accompanying the development of technology. In respect to social and economic development, it is important to prepare young people, both boys as well as girls, with comprehensive knowledge and a basic education in technology for the benefit of their future life. Teachers' assessment of craft and technology education, from two different periods of time, are compared in light of two different national curricula in order to explain possible changes in teachers' conceptions related to the teaching methods of technology and examines teachers' opinions on the methods of technology education. This research attempts to find answers to the questions: What are teachers' attitudes towards teaching methods at the two different periods of time? What changes occurred in the teaching methods of the syllabi in light of the curricula adoptions in 2004 and in 2011? The research is based on questionnaire surveys administered across Estonia in 2004 and 2011. Findings indicate that during the two periods in question the teaching methods used by the teachers of technology education in Estonian schools shifted from the traditional approach to teaching towards a more constructivist approach. The researcher concludes that the teaching methods applied in technology education must keep current. Teaching would greatly benefit from the introduction of more activating teaching methods, particularly those connected with applying technology.
\end{abstract}

Keywords: technology education, teaching, teaching methods, sustainability

\section{Introduction}

Every day we experience a rapid development and expansion of technology and innovation. Society increasingly needs people who are able to cope with using, managing and planning different fields of technology. Also the idea of the sustainability of education supports the thoughts and actions that innovative and motivated people instinctively direct towards sustainability. Technology education is a part of general education and can play an important role in promoting sustainable production and consumption 
(Pavlova, 2006). One prerequisite for guaranteeing such sustainability is adopting innovated teaching methods into the subject lessons.

In 2010, the schools in Estonia adopted the National curriculum for basic schools (Põhikooli riiklik õppekava [National curriculum for basic schools], 2011), which, in respect to technology education, grants learners a larger number of options than before, including co-learning possibilities for boys and girls as well as project work.

The learner is an active participant in the teaching and learning process, who, according to his/her abilities participates in setting the goals for his/her learning, learns independently and with peers, learns to assess peers as well as himself/ herself, to analyse and manage his/her learning. Acquiring new knowledge is based on learner's previous knowledge, and, on the basis of the new information, the learner constructs his/her knowledge. The acquired knowledge is applied in new situations or when the learner solves problems, makes choices, discusses about the correctness of statements, arguments his/her viewpoints and in further studies (Põhikooli riiklik õppekava [National curriculum for basic schools], 2011, Chapter 3).

The curriculum is based on the social-constructivist approach where the learner is not a passive receiver of knowledge but is an active participant in learning. Learners interact with the world around them and construct their own knowledge models based on their experiences; these include models of how the physical and the social worlds operate (Owen-Jackson \& Steeg, 2007). The teacher plays a key role in making sure that all the learning activities operate as smoothly as possible and are effective in fostering the intended learning outcomes (Kyriacou, 2012). Whereas direct instruction tends to be teacher-centred, indirect instruction is more learner-centred (Kellough \& Kellough, 2011). The ideas of pupils emerging through their talk are scaffolded or framed by the teacher putting in a 'step' or as questions at appropriate junctures (Burton, 2009). Learner-centred curricula, referring to learning through practical application or doing based on the momentary interests of children, is a collective term which refers to the rejection of teacher-directed learning (Marsh, 1997). Parikka, Rasinen and Ojala (2011) posit that it is important to look for viewpoints and methods which can be implemented in everyday school life to motivate pupils for ethical-moral studies. Teaching methods easily implemented in a classroom include modelling (showing pupils how to do or think about a difficult task), scaffolding (providing maximum support at the outset which is gradually withdrawn), coaching (assisting pupils while they are solving a problem), articulation (getting pupils to express their ideas), reflection (getting pupils to reflect on their activities) and collaboration (working with other pupils), exploration (working on non-routine problems) (Muijs \& Reynolds, 2005).

Watkins, Carnell and Lodge (2007) point out that effective learning can occur when the teacher is invisible, when people are willing to be vulnerable, when learners take an active role in their learning experiences and after a failed attempt. Indirect instruction does not need a teacher to give learners knowledge but happens when classroom management brings about a positive atmosphere where learners want to learn (Watkins, Carnell \& Lodge, 2007). Teachers should encourage pupils to construct meaning by structuring learning activities around big ideas and explorations as well as giving them sufficient time to explore concepts thoroughly to connect new knowledge to what pupils already know (Muijs \& Reynolds, 2005). Today, the approach in technology education that 
focused on practical craft skills, an apprentice-based 'show, copy and practice' teaching model, has shifted to the background (Banks, 2009). Parikka and Kantola (2001) point out changes in the trends of learners' technical education: the teacher no longer mediates the information to the learner but rather consistently develops different aspects in the learner's thinking and practical activity, along with experimentation and exploration.

"Modular technology education" and "technological problem solving", entailing an approach in which learners design and build solutions to problems posed by the teacher, are now more widespread than the project-from-plans method (Sanders, 2001). This new conceptualisation of technology education emphasises new activating approaches in teaching towards a solution of technical problems (work of the pupils in teams, system of module teaching, use of the Internet etc.), in support of education towards independent and creative work (Novakova, 2006). Parikka and Rasinen (2009) expressively bring forth the educational essence of today's technology education.

Learning is viewed as ... active mental activity that is led by intrinsic models and adopted study goals related to various questions and competent achievements that have previously developed in the memory. Reproducing and assessing knowledge and skills stored in the memory is an important part of the learning activity. The learner's ability to assess, observe and manage his or her own progress is considered to be vital. When teaching technology, it is important to see the problems and to work out solutions for them. Thereat, the central focus is on supporting learner's development towards self-regulation (p. 39).

Technology education should enable pupils to develop their technological ability through opportunities to take part in activities of an extended nature, which offer an advantage of knowledge, understanding and skills from many areas curriculum (Layton, 1993). The fields of technology and technology education place great emphasis on problem solving and application as teachers strive to promote technological literacy (Koch \& Sanders, 2011).

The approach to teaching methods is highly dependent on teachers' readiness and abilities to apply innovative methods. In the choice of teaching method, a teacher needs to have in mind many important aspects. Meriläinen (2006) notes that, when considering suitable teaching methods, one must remember that the chosen methods should always be relevant from the point of view of educational objectives, the content taught, the readiness and abilities of the teachers as well as the learners, in addition to the point at which the learners are located on the continuum of learning and development. According to the analysis of technology education in the curricula of five European Union countries (Austria, Estonia, Finland, France and Germany), Rasinen, Virtanen and Miyakawa (2009) point out that:

The pedagogical means and methods are very similar in all five countries. Hands-on activities are emphasized in all curricula. (...) Such learning methods as observation, exploration, experimenting, discovery, analysis, problem solving, design, manufacture and innovation are expressed. (...) Also both individual work and co-operative learning methods are encouraged (p.71).

Many researchers (Doherty \& Canavan, 2006; Jones \& Compton, 2009; Mita, Matsuda, Iwaki, \& Furuta, 2006) stress that the new content of technological studies together with its emphasis on the integration of technologies, coupled with an approach towards supporting learning that give emphasis to project work, resource-based learning 
and using technology in a problem solving context - all combine to mark the distinctiveness of this course from anything that has proceeded.

Experts accentuate self-directed and independent discovery or investigation; furthermore, they relate evaluation of their significance and meaning as well as team- working methods (Parikka, 1998). Järvinen, Karsikas and Hintikka (2007) bring out ideas about teaching technology:

If a child is able to identify a problem and proves to be successful in solving it in a way that the solution meets personal needs, it results in a very positive experience. (...) The authors wish to encourage teachers who are not already doing so to try an open-ended approach to technology teaching. (...) When the final outcome of children's problem solving processes is unknown to them, boredom and disinterest is replaced with thrilling anticipation (p. 50).

The methodological challenges, concerning learning by doing and similar approaches, are not without significance either. Parikka (1998) accentuates the importance of planning and problem-solving skills needed in daily life as well as of learning skills, both independent and those involving joint responsibility. Parikka and Ojala (2008) emphasise that learners have opportunities to develop their creativity and design skills, make choices, take risks, cope with uncertainties and constraints, learn to commit themselves to the chosen aims, take responsibilities and experience success as the result of their own entrepreneurial activity.

The aim of the current research is to probe the question: What are teachers' attitudes towards teaching methods at the two different points of time-2004 and in 2011?

\section{Methodology}

The research compares and analyses the changes in the teaching methods of technical subjects in Estonia and seeks to explain which teaching methods guarantee the sustainability of modern technology education and the development of learners' personality.

\section{Sample}

Initially, in the autumn of 2004, 482 questionnaire surveys were sent out to the teachers of craft and technology education in the general education schools of the country; 157 were returned. At the beginning of 2011, the author sent out 417 questionnaire surveys to the technology teachers in general education schools; 109 were returned. The 2004 data collection is referenced as Phase 1 , and the 2011 data collection is referenced as Phase 2. Most of the respondents were men. In Phase 1, 149 of the respondents were men, and 8 - were women. In Phase 2, 103 of the respondents were men, and 6 - were women. Across the years, the gender distribution of the teachers of technical subjects has remained similar in that the greatest proportion is male.

\section{Instrument}

Assessing the teaching methods, the author asked the teachers of technical subjects to formulate their opinions based on the usefulness of teaching and on its importance in everyday life as well as to reflect on what is vital in view of the future. The questionnaire 
is based on a survey used by Rasinen (2000), which was translated into Estonian. The questionnaire contained four different blocks of themes: objectives, contents, methods and material-technical situation. In this paper, only teachers' opinions on different teaching methods will be examined and analysed. Altogether 36 substantial questions on the teaching methods of technology education were posed to the teachers. A sixpoint Likert scale was employed ( 0 = cannot answer; I don't know; 1 = has not been useful; 2 = has been useful or important only to a little amount; $3=$ to a certain amount useful or important; 4 = rather useful and important; 5 = very useful and important). The value "0" was not taken into account when analysing the results.

\section{Method}

Analysing the results and comparing the aggregates, a $t$-test was administered to determine the significant probabilities of average differences between Phase 1 and Phase 2 , using the average values to illustrate the results on the graph (Figure 1). Further, in order to determine the mutual relations between the primary characteristics and to determine latent variables (hidden characteristics), a factor analysis was applied to identify characteristics with common elements and, based on these, to form the factors that describe a broader common aspect (Niglas, 2013). The statistical data processing software SPSS 18.0 was utilised to process the data; values of the factor loads were obtained by a rotated factor matrix (Varimax method). Factor analysis enables one to express data through a linear network of interconnected characteristics which best expresses the data's preliminary mutual relations, or, to put it another way, the correlation between the measured characteristics is reduced to the correlation between the measured characteristics and the common factors as well as possible (Tooding, 2007). Based on the obtained factors, it is possible to give a broader and more general description of the changes in the teaching methods between Phase 1 and Phase 2 as well as to point out changes in teachers' assessment of teaching methods at the different points of time.

Based on the conceptual and interpretative aspect of the teaching methods of technology education (Tooding, 2007) and keeping in mind the statistical parameters, the eight-factor model proved to be the most suitable, which was formed on the basis of 36 basic characteristics, originally given as the survey questions. Thus, the 36 characteristics are replaced with eight factors, which give a more equable and trustworthy picture of general views and assessment, than if the specific basic characteristics are analysed separately. The names of the factors most expressively reflect the qualities within the primary characteristics. These descriptors rest on the teaching methods of technology education as interrelated with practical tasks and pertinent activities.

\section{Research Findings}

Comparing the questions of a survey concerning the methods of teaching in Phase 1 and Phase 2 using a $t$-test, it became evident that only in the case of statement Experimenting, the averages of the answers in the two studies had statistically significant differences, $\mathrm{p}=.034<.05$. In 2011, the statement related to experimenting had the biggest positive increase compared to other questions concerning teaching methods. Phase 1: $\mathrm{M}=3.85, \mathrm{SD}=.948$ and Phase $2: \mathrm{M}=4.10, \mathrm{SD}=.935$. Figure 1 shows the averages of all questions in the decreasing order of general averages at the different points of time. 


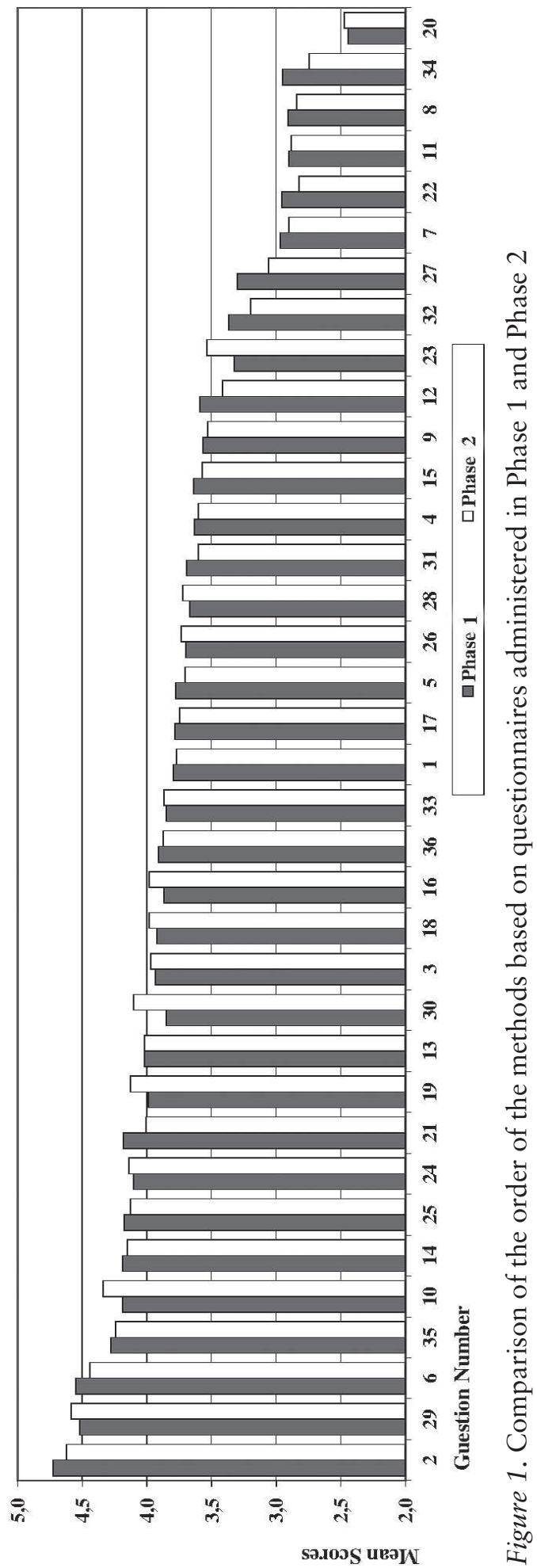


Based primarily on the constructive aspect, while at the same time keeping in mind the statistical parameters, the eight-factor model, formed on the basis of 36 primary characteristics, proved to be the most optimal. Based on the analysis of the results of teachers' questionnaires in Phase 1, it appears that eight factors explain $63 \%$ of the whole variability of the basic characteristics; in Phase 2, eight factors explain $64 \%$ of the whole variability. This is high and sufficient enough for the model with the eight factors to be regarded as good.

Analysing the obtained factors and their primary characteristics in Phase 1 and Phase 2, it became evident that a series of factors emerged which could have the same name in the both research phases: Learner-centred activity; Practical activity; Educational outing; Teacher-centred activity and Production activity. However, the primary characteristics of all the factors with the same name are not completely the same. Furthermore, three factors in the two studies could not be identified with the same name as a set of pairs. In order to describe the factors, Table 1 and Table 2 for Phases 1 and 2 respectively, present an overview of percentages on a specific factor as received from the teachers based on its usefulness or importance, according to the provided assessment scale.

Table 1

Distribution of the Factors of Teaching Methods in Phase 1 in Percentages

\begin{tabular}{|c|c|c|c|c|c|}
\hline Factors & 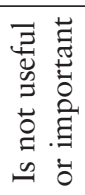 & 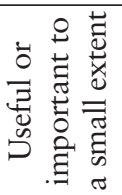 & 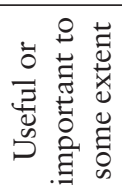 & 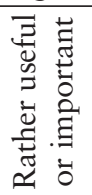 & 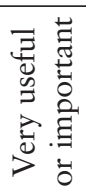 \\
\hline Learner-centred activity & 20.6 & 17.4 & 20.0 & 21.9 & 20.0 \\
\hline Research and solving problems & 19.9 & 17.9 & 25.0 & 18.6 & 18.6 \\
\hline Practical activity & 24.2 & 17.8 & 26.1 & 16.6 & 15.3 \\
\hline Instructions and homework & 15.5 & 20.6 & 18.1 & 21.9 & 23.9 \\
\hline Educational outing & 16.8 & 22.6 & 23.2 & 23.2 & 14.2 \\
\hline Teacher-centred activity & 17.8 & 15.9 & 34.4 & 15.3 & 16.6 \\
\hline Cooperation & 17.2 & 25.5 & 21.0 & 17.2 & 19.1 \\
\hline Production activity & 14.9 & 17.5 & 23.4 & 24.7 & 19.5 \\
\hline
\end{tabular}

Table 2

Distribution of the Factors of Teaching Methods in Phase 2 in Percentages

\begin{tabular}{|c|c|c|c|c|c|}
\hline Factors & 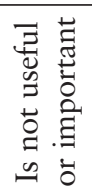 & 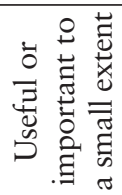 & 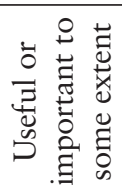 & 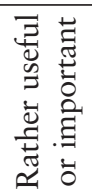 & 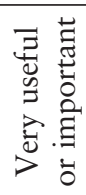 \\
\hline Learner-centred activity & 19.3 & 22.0 & 20.2 & 19.3 & 19.3 \\
\hline Cooperation and solving problems & 17.4 & 22.0 & 21.1 & 22.9 & 16.5 \\
\hline Teacher-centred activity & 20.2 & 29.4 & 12.8 & 21.1 & 16.5 \\
\hline Educational outing & 22.9 & 11.0 & 31.2 & 16.5 & 18.3 \\
\hline Outdoor learning and homework & 16.5 & 22.9 & 17.4 & 24.8 & 18.3 \\
\hline Practical activity & 14.7 & 20.2 & 37.6 & 14.7 & 12.8 \\
\hline Supervising & 4.7 & 32.1 & 0.0 & 63.2 & 0.0 \\
\hline Production activity & 15.5 & 34.0 & 0.0 & 39.2 & 11.3 \\
\hline
\end{tabular}




\section{Common Factors in Phase 1 and Phase 2}

The common factors in Phase 1 and Phase 2 are Learner-centred activity; Practical activity; Teacher-centred activity; Educational outing and Production activity.

The factor Learner-centred activity has obtained high assessment from teachers in the results of both studies, the aspect of usefulness and importance of about $80 \%$ (Table 1 and Table 2). The primary characteristics of the factor describe the teaching methods closely related to the factor - distance working or completing assignments via the Internet, using online materials, working on the computer etc. In Phase 1, the first six primary characteristics have strong factor loading, correspondingly between .632 and .745 . In Phase 2, the first five primary characteristics have strong factor loading, correspondingly between .615 and .758, which are proof of teachers' high confidence in the factor. In Phase 2, the factor Practical activity has received higher assessment compared to Phase 1. In Phase 2, 85.3\% of the teachers see this factor as useful or important, in Phase 1 being $75.8 \%$. The factor Practical activity contains activities necessary for learners to carry out practical activities, including practising techniques. The first three primary characteristics of Phase 1 mostly describe the examples of practical activities, independent work in a workshop, working by the aid of manuals and instructions provided by the teacher, the corresponding factor scales being .608; .665;.689. Two primary characteristics of Phase 2 describe the factor, which are different from the primary characteristics of the previous Phase, so frontal work, producing identical working objects at a time and illustrating, the corresponding factor scales being .772 and .506., which are proof of teachers' high confidence in the factor. The factor Teacher-centred activity received high assessment from teachers in the results of both Phase 1 and II, the aspect of usefulness and importance in Phase 1 being over $82 \%$, and, in Phase 2 - as $77 \%$ (Table 1 and 2 respectively). The primary characteristics of the factor describe activities common to teachers: explaining, instruction in work process, working by the aid of manuals and instructions provided by the teacher, using textbooks and teaching aids etc. In Phase 1, the first two primary characteristics have strong factor loading, .734 and .732 correspondingly. In Phase 2, all three primary characteristics have strong factor loading, .673; .694 , and .701 correspondingly, which are proof of teachers' high confidence in the factor. The factor Educational outing received high assessment from teachers in the results of Phase 1 , the aspect of usefulness and importance being $83 \%$; in Phase 2 , the teacher assessment are lower, over 77\% (Table 1 and 2 respectively). The primary characteristics of the factor are educational trips to enterprises, discussions, cooperation with partner enterprises. The factor loading of the primary characteristics of the factor in Phase 2 are higher $(.633 ; .729 ; .742)$ compared to the factor scale of Phase 1 (.520; $.544 ; .587 ; .706)$. The factor Production activity has obtained high assessment from teachers in the results of both research phases, the aspect of usefulness and importance of about $85 \%$ (Table 1 and 2 respectively). The factor is characterised by productionrelated activity. In Phase 1, the factor has high connection with primary characteristics: serial production, frontal work, corresponding factor scales being .751 and .647. In Phase 2, only one of the aforementioned primary characteristics has been brought out, the factor scale of which is .726 and is a proof of teachers' high confidence in the factor. 


\section{Unique Factors in Phase 1}

As a result of factor analysis, three unique factors - Research and solving problems; Instructions and homework and Cooperation - were formed in Phase 1. More than $80 \%$ of the teachers regarded Research and solving problems as useful or important in school work, which includes statements related to research, experimenting and analysing as well as solving problems (Table 1). The factor has a strong correlation with the first three primary characteristics: treating and solving problematic situations (.737), examining and experiencing (.678), analysing (.600), which are proof of teachers' high confidence in the factor. More than $84 \%$ of the teachers regarded the factor Instructions and homework as useful or important in school work (Table 1). The factor contains activities in the field of technical activities which learners can carry out at home and in their free time: worksheets or workbooks and homework. The factor loading of the two primary characteristics are .769 and .590 respectively. More than $82 \%$ of the teachers regarded the factor Cooperation as useful or important in school work (Table 1). The factor has a strong correlation with the primary characteristics of group work (.795).

\section{Unique Factors in Phase 2}

As a result of factor analysis, three unique factors were formed in Phase 1: Cooperation and solving problems; Outdoor learning and homework; Supervising. The factor Cooperation and solving problems includes tasks where learners cooperate: Treating and solving problematic situations (.783), discussions (.727), analysing (.700), project and team work (.677), group work (.609) and experimenting (.510). More than $82 \%$ of the teachers regarded the factor as useful or important in school work. The factor has a strong correlation with six presented primary characteristics, which is proof of teachers' high confidence in the factor. The factor Outdoor learning and homework describes learners' activities performed outside the school: learning in the nature (.600) and homework (.588). The correlations are rather modest. The biggest percentage, more than 95 $\%$ of the teacher regarded the factor Supervising as useful or important in school work (Table 2). The factor contains only one primary characteristic - instruction in work process - and has high factor score $(0.805)$, which is proof of teachers' high confidence in the factor.

\section{Discussion and Conclusions}

On the level of teaching methods, teachers' assessment of craft and technology education (Phase 1) and technology education (Phase 2) are rather similar than different, answering the research question: What changes have occurred in teachers' assessment of the methods of teaching at the two points of time - 2004 and 2011? Statistically significant difference can only be seen in assessment of the statement Experimenting, where the results of Phase 2 express more positive attitudes. In Phase 2, the bigger interest in the statement Experimenting most probably reflects the change in stress in the new syllabus of technology education, according to which a greater stress is on experimenting with practical tasks, experiencing and experimenting. On the basis of the results of the factor analysis in the both research phases, teachers' assessment of factors are equally high. As a result, the factors characterising the teaching methods, 
bearing the same names were formed: Learner-centred activity; Practical activity; Educational outing; Teacher-centred activity and Production activity. In Phase 2, the factor Outdoor learning and homework was formed, the factor loading of which was low. However, the factor Supervising in Phase 2 received a high factor loading, which shows teachers' strong attitude towards supervising as a method of teaching. The teaching methods, compared on the basis of the two syllabi, highlighted as the main differences the opinion of teachers, according to which in the first phase during 2004, the factor Teacher-centred activity is singled out, the factor which Banks (2009) calls an apprenticebased 'show, copy and practice' teaching model; whereas, in the second phase during 2011, the factor received considerably lower assessment. This researcher posits that, year after year, teachers' explanations and instructions have an increasingly less impact on the learning process; there should be an increase in learners' thinking and experimenting and finding solutions. Thus, over the years, teachers' opinion on the factor's usefulness has considerably changed.

The factor Production activity faced the same situation. Based on the results of the first phase, it could be elicited that too much stress is laid on the factor Production activity, where more attention should be paid to promoting learners' creativity and applying more active teaching methods in technology education. Whereas, in the later phase, the number of respondents supporting the factor was considerably lower.

The factor Learner-centred activity had similar results in both of the phases. It is necessary that learners start practising independent learning gradually from the very beginning, for this ensures that further independent learning is easier to acquire. Teachers hold the opinion that a considerable importance in completing learning tasks is on individual work and on doing it via the Internet, using computers in the teaching and learning process. Also, Parikka and Rasinen (2009) stress the need for adopting a similar teaching method. However, it should be monitored in class that learners have independent tasks fitting for their ability level and age.

Also, the factors Research and solving problems and Cooperation and solving problems received similar teacher assessment at the different times. High assessment were given to solving problems, research, analysing and discussing. In technology education lessons, learners often have to think and solve various tasks to which they initially do not have an answer. They find solutions through experimenting and testing, and experiencing. Many researchers (Jones \& Compton, 2009; Parikka, 1998; Rasinen et al., 2009) point out this important approach in technology education.

Based on the results of Phase 1, the factor Practical activity received rather modest assessment from the teachers. In Phase 2, the factor received high assessment. This leads us to believe that teachers mostly engage learners in the form of practical activities, but have not succeeded in spotlighting this fact very well in their responses. This factor could be regarded as a traditional form of practical work, because in many of the Estonian schools teaching is mostly based on this factor.

The results of the factor Educational outing received higher assessment from the teachers in Phase 2. This factor shows that, in addition to school lessons, teachers value the need to introduce company workplaces to their learners and, if possible, to cooperate with the companies, to introduce production to learners via videos and later discuss what was seen. In introducing new production techniques and machines as well as modern production processes, an important role is played by educational outings to visit company sites and by mutual cooperation, if possible. 
The relative importance of the factor Cooperation in school work must increase, because it is through various project-based activities that learners learn to do the same work they will come into contact with in their future work life, and, thus, it is important for them to develop their project-based activity. That children's understanding of technology can be achieved by enabling them to work in the same spirit as real technologists do. This approach brings authenticity to the experience (Järvinen, Karsikas, \& Hintikka, 2007).

On the basis of this research, it is possible to conclude that the teaching methods applied in technology education must keep current. Teaching would greatly benefit from the introduction of more activating teaching methods, especially those which are connected with applying technology: web-based materials, using mobile applications etc. Teachers continually consider practical activity and supervising the work process as important parts of technology education lessons. However, more attention should be paid to learners' independent work and cooperation, which received slightly lesser assessment. Using different and innovative teaching methods in technology education enhances the development of learners' personality and creates opportunities for the sustainable development of the teaching.

It is important that knowledge which one has is applied or put into practise in an innovative, "creatively new" way. Innovation process is associated with brainstorming, problem solving, innovativeness, inventiveness, design, modelling, evaluation, experimental approaches and also creativity, aesthetical and ethical aspects. The aim of the activity is that awareness raising, learning and design processes are integrated to enable application and create innovative solutions. In technology education learning by doing method has a central role in innovative problem solving processes (Rasinen et al., 2009, p. 78).

More use should be made of innovative teaching methods, which enable the use of technology in a more diverse way. This would increase learners' interest in the topics being taught and help them learn in cooperation. Accordingly, iTecEC has been created, which aims at promoting the development and application of information technology at school (Sillaots, 2012).

There are several methods that could be studied and piloted as a part of teaching technology education. For example, in case of design-based learning approaches, the experts point out that this approach helps to prepare learners for professional practices by bridging the gap between education and engineering preparation for industry settings (Gómez Puente, van Eijk, \& Jochems, 2012). It is suggested that teaching should have more place of values and beliefs as an important aspect that can be overlooked in curriculum development and implementation, as can environmental issues (Jones, 2009). Also, researchers are seeking for new ways of applying such methods as problem solving, designing, modelling and systems thinking (Banks, 2009).

\section{Acknowledgement}

The paper was supported by the European Social Fund (grant nr. 1.2.0401.090070). 


\section{References}

Banks, F. (2009). Research on teaching and learning in technology education. In A. Jones \& M. De Vries (Eds.), International handbook of research and development in technology education (pp. 373-389). Rotterdam: Sense Publishers.

Burton, D. (2009). Why pupils learn. In S. Capel, M. Leask \& T. Turner (Eds.), Learning to teach in the secondary school: A companion to school experience ( $5^{\text {th }}$ ed.) (pp. 251-266). London: Routledge.

Doherty, R. A., \& Canavan, B. (2006). Mapping reform in Scotland's technology education curriculum: Change and curriculum policy in the compulsory sector. In M. De Vries \& I. Mottier (Eds.), International handbook of technology education (pp. 347-375). Rotterdam: Sense Publishers.

Gómez Puente, S. M., van Eijk, M. W., \& Jochems, W. M. (2012). A sampled literature review of design-based learning approaches: a search for key characteristics. International Journal of Technology and Design Education, 23(3), 717-732. doi: 10.1007/ s10798-012-9212-x

Jones, A. (2009). Looking back to look forward: The future of technology education. In A. Jones \& M. De Vries (Eds.), International handbook of research and development in technology education (pp. 685-692). Rotterdam: Sense Publishers.

Jones, A., \& Compton, V. (2009). Reviewing the field of technology education in New Zealand. In A. Jones \& M. De Vries (Eds.), International handbook of research and development in technology education (pp. 93-104). Rotterdam: Sense Publishers.

Järvinen, E. M., Karsikas, A., \& Hintikka, J. (2007). Children as innovators in action a Phase of microcontrollers in Finnish comprehensive schools. Journal of Industrial Teacher Education, 18(2), 37-52.

Kellough, R. D., \& Kellough, N. G. (2011). Secondary school teaching. Boston: Pearson Education.

Koch, D., \& Sanders, M. (2011). The effects of solid modeling and visualization on technical problem solving. Journal of Technology Education, 22(2), 3-21.

Kyriacou, C. (2012). Teaching. In J. Arthur \& A. Peterson (Eds.), The Routledge companion to education (pp. 107-114). New York: Routledge.

Layton, D. (1993). Technology's challenge to science education: Cathedral, quarry or company store? Buckingham: Open University Press.

Marsh, C. J. (1997). Planning, management and ideology: Key concepts for understanding curriculum 2. London: Falmer Press.

Meriläinen, M. (2006). Guidelines on "how to approach teaching and learning?" Joensuu: Joensuun yliopiston kirjasto.

Mita, S., Matsuda, T., Iwaki, J., \& Furuta, T. (2006). A change of industrial technology education curriculum and development of a design learning support system for technology education. In M. De Vries \& I. Mottier (Eds.), International handbook of technology education (pp. 241-252). Rotterdam: Sense Publishers.

Muijs, D., \& Reynolds, D. (2005). Effective teaching: Evidence and practice. London, England: Sage Publications.

Niglas, K. (2013). Faktoranalü̈̈s [Factoranalysis]. Retrieved from http://minitorn.tlu.ee/ $\sim$ katrin/cmsSimple/uploads/opmat/faktor.pdf

Novakova, H. (2006). Innovative of the concept and content of technology education in the Czech Repuplic in context with their development in the countries of central 
Europe. In M. De Vries \& I. Mottier (Eds.), International handbook of technology education (pp. 463-475). Rotterdam: Sense Publishers.

Owen-Jackson, G., \& Steeg, T. (2007). The role of technical knowledge in design \& technology. In D. Barlex (Ed.), Design \& technology - for the next generation (pp. 171-185). Whitchurch, England: Cliffe \& Company.

Parikka, M. (1998). Teknologiakompetenssi. Teknologiakasvatuksen undistamishaasteita peruskoulussa ja lukiossa [Technological competence. Challenges of reforming technology education in the Finnish comprehensive and upper secondary school]. Jyväskylä: Jyväskylän Yliopisto.

Parikka, M., \& Kantola, J. (2001). Kasvatusoppillisesta veistosta teknologiakasvatukseen [From educational science to technology education]. Tekninen Opettaja [Technology teacher], 1, 18-19.

Parikka, M., \& Ojala, A. (2008). Entrepreneurship and technology education in the context of information society. Journal of the Japan Society of Technology Education, 50(1), 9-16.

Parikka, M., \& Rasinen, A. (2009). Teknologiakasvatus tutkimuskohteena [Technology education as a research object]. Jyväskylä: Jyväskylän yliopistopaino.

Parikka, M., Rasinen, A., \& Ojala, A. (2011). Technology education. In M. De Vries (Ed.), Positioning technology education in the curriculum (pp. 133-143). Rotterdam: Sense Publishers.

Pavlova, M. (2006). Comparing perspectives: Comparative research in technology education. In M. De Vries \& I. Mottier (Eds.), International handbook of technology education (pp. 19-32). Rotterdam, Netherlands: Sense Publishers.

Põhikooli riiklik õppekava [National curriculum for basic schools]. (2011). Retrieved December 12, 2012, from https://www.riigiteataja.ee/akt/114012011001?leiaKehtiv

Rasinen, A. (2000). Developing technology education: In search of curriculum elements for Finnish general education schools (Doctoral dissertation). Retrieved from https://jyx.jyu.fi/dspace/bitstream/handle/123456789/13388/9513924017.pdf? sequence $=1$

Rasinen, A., Virtanen, S., \& Miyakawa, H. (2009). Analysis of technology education in the curricula of five EU countries and challenges of technology education - the Finnish perspective. In G. Hoepken, L. S. Lee, H. Miyakawa \& A. Ojala (Eds.), Cross border: International cooperation in industrial technology education (pp. 6783). Aichi: Aichi University of Education.

Sanders, M. (2001). New paradigm or old wine? The status of technology education practice in the United States. Journal of Technology Education, 12(1), 35-55.

Sillaots, M. (2012). Innovaatilised õpistsenaariumid iTec projekti näitel [Innovative learning scenarios basing on the example of the iTec project]. E-õppe Uudiskiri [E-learning newsletter]. Retrieved from http://undiskiri.e-ope.ee/? $p=2771$

Tooding, L. M. (2007). Andmete analüüs ja tõlgendamine sotsiaalteadustes [Data analysis and interpretation in social sciences]. Tartu: Tartu Ülikooli Kirjastus.

Watkins, C., Carnell, E., \& Lodge, C. (2007). Effective learning in classroom. London: Paul Chapman Publishing.

Correspondence concerning this paper should be addressed to Mart Soobik, a PhD candidate, MA, Department of Educational Science, Institute of Educational Sciences, the University of Tallinn, Uus-Sadama 5, Tallinn 10120, Estonia. Tel: +372 56499135. Email: mart@tehnoloogia.ee 